University of Nebraska - Lincoln

DigitalCommons@University of Nebraska - Lincoln

Faculty Publications from Nebraska Center for Research on Children, Youth, Families, and Schools
Children, Youth, Families \& Schools, Nebraska Center for Research on

2013

\title{
Head Start Classrooms and Children's School Readiness Benefit from Teachers' Qualifications and Ongoing Training
}

\author{
Seung-Hee Claire Son \\ University of Utah, s.claire.son@utah.edu \\ Kyong-Ah Kwon \\ Georgia State University \\ Hyun-Joo Jeon \\ University of Nevada - Reno, hyunjooj@unr.edu \\ Soo-Young Hong \\ University of Nebraska - Lincoln, shong5@unl.edu
}

Follow this and additional works at: https://digitalcommons.unl.edu/cyfsfacpub

Part of the Educational Assessment, Evaluation, and Research Commons, and the Pre-Elementary,

Early Childhood, Kindergarten Teacher Education Commons

Son, Seung-Hee Claire; Kwon, Kyong-Ah; Jeon, Hyun-Joo; and Hong, Soo-Young, "Head Start Classrooms and Children's School Readiness Benefit from Teachers' Qualifications and Ongoing Training" (2013). Faculty Publications from Nebraska Center for Research on Children, Youth, Families, and Schools. 28. https://digitalcommons.unl.edu/cyfsfacpub/28

This Article is brought to you for free and open access by the Children, Youth, Families \& Schools, Nebraska Center for Research on at DigitalCommons@University of Nebraska - Lincoln. It has been accepted for inclusion in Faculty Publications from Nebraska Center for Research on Children, Youth, Families, and Schools by an authorized administrator of DigitalCommons@University of Nebraska - Lincoln. 


\title{
Head Start Classrooms and Children's School Readiness Benefit from Teachers' Qualifications and Ongoing Training
}

\author{
Seung-Hee Claire Son ${ }^{\mathrm{a}}$, Kyong-Ah Kwon ${ }^{\mathrm{b}}$, Hyun-Joo Jeon ${ }^{\mathrm{c}}$, \\ Soo-Young Hong ${ }^{\mathrm{d}}$
}

\begin{abstract}
Background Teacher qualifications have been emphasized as a basis of professional development to improve classroom practices for at-risk children's school readiness. However, teacher qualifications have often not been compared to another form of professional development, in-service training.

Objective The current study attempts to investigate contributions of multiple types of professional development to school readiness skills of low-income preschoolers. Specifically, we examined the significance of teachers' education level, degree, teaching certificate, teaching experiences as well as specialized in-service training and coaching support as these teacher trainings are linked to preschoolers' school readiness through proximal classroom practices.

Method We used a multi-level path analysis to examine multiple pathways from teachers' professional development to classroom environments and school readiness with Head Start Family and Child Experiences Survey 2003 (N=2,159).

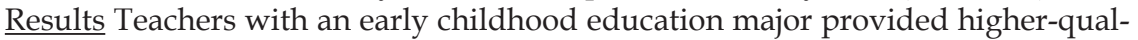
ity provision for learning and social-emotional practices in the classroom; teachers who received coaching provided higher-quality social-emotional and parent involvement practices. Further, children in higher-quality social-emotional classrooms had better math skills, social skills and learning behaviors; children in the classrooms with higher-quality parent involvement practices had higher receptive vocabulary and parent-reported social skills and positive approaches to learning. Conclusions Along with early childhood education degree, ongoing coaching support would work effectively, improving classroom environments and a broad array of school readiness skills of at-risk children.
\end{abstract}

Keywords: Head Start, School readiness, Teacher education, Teacher qualifications, Professional development, In-service training, Coaching, Classroom quality

\footnotetext{
aUniversity of Utah, Salt Lake City, Utah, USA; s.claire.son@utah.edu; corresponding author ${ }^{\mathrm{b}}$ Georgia State University, Atlanta, Georgia, USA

'University of Nevada, Reno, Reno, Nevada, USA

dUniversity of Nebraska-Lincoln, Lincoln, Nebraska, USA
} 


\section{Background}

The nation's focus on children's school readiness makes it critical to investigate indicators and predictors of high-quality early education experiences (Ackerman 2004). The quality of early education is especially important to at-risk children from low-income families as a protective factor for their development and school readiness (Caughy et al. 1994; Desimone and Long 2010).

As part of quality predictors of early care and education especially for at-risk children, federal and state governments have invested in strengthening teacher qualifications (Ackerman 2004; Burchinal et al. 2008). For example, Head Start programs have educational requirements that state by September 2013 at least $50 \%$ of the teachers in center-based programs must have a baccalaureate or advanced degree in early childhood education or a baccalaureate or advanced degree in any subject, with related coursework and teaching experiences (Administration for Children and Families 2008a). This decision was based on research evidence which showed that teachers who had higher qualifications, such as a college degree, teaching experiences and certification, tended to provide young children with higher-quality classroom experiences, which seem to facilitate the children's school readiness skills (e.g., Burchinal et al. 2002; Tout et al. 2005). However, studies of teacher qualifications provide limited evidence: teacher qualifications are only one part of professional development. Further, there is an absence of definition of teacher qualification or profession development with various terms used in the field (Maxwell et al. 2005). Teachers' professional development can also take or utilize different forms of on-going training: in-service training, such as specialized training workshops and coaching support (Buysse et al. 2009; Zaslow and Martinez-Beck 2006). Focusing only on strengthening teacher qualifications may not be enough to lead to substantial improvements in professional development and children's school readiness.

Finally, the patterns of associations are not clear among professional development and children's school readiness. The process model of early care and education (NICHDECCRN 2002a; Vandell and Wolfe 2000) suggests that distal aspects of early education will influence children's outcome through proximal and process aspects of classroom practices. Based on this model, it is highly unlikely for distal variables, such as teacher qualifications or their in-service training, to work directly to improve school readiness skills, without involving any proximal changes in classroom environments. In other words, classroom processes should be addressed as a mechanism that leads to changes in children's outcomes, and professional development needs to be considered as a way to improve school readiness through classroom processes. However, these hypothesized pathways have not been directly tested with each of the multiple forms of professional development.

Thus, the present study attempts to examine multiple forms of professional development considered in the field (Maxwell et al. 2005) and compares the contribution of each form of professional development to low-income children's school readiness skills through their pathways to classroom environments. Specifically, we used Buysse et al. (2009)'s definition of professional development and examined multiple forms of teacher qualifications (i.e., education level, major, certification, teaching experiences) and in-service training (i.e., specialized in-service training and coaching) and their contribution to children's school readiness through the process of classroom environments (i.e., provision for learning, social-emotional practices, parent involvement practices) (NICHD-ECCRN 2002a). 
The Importance of Teacher Qualifications to Classroom Environments and Children's Outcomes

There has been extensive research examining contributions of teacher qualifications including teachers' education, credentials and experiences (Lamb and Ahnert 2007). Previous findings highlighted the importance of more years of formal education for early care and education teachers by finding that those teachers holding at least a bachelor's degree tended to provide higher-quality classroom practices (Barnett 2003; Howes et al. 2003; Tout et al. 2005), which seems to positively contribute to children's outcomes (Gerde and Powell 2009). According to a meta-analysis (Kelley and Camilli 2007), the overall correlation between teachers' education level and the quality of classroom environments was statistically significant, although its effect size was moderate.

Several studies found that teachers' field of study or major in early childhood education/child development (ECE/CD) was more important than the education level or a college degree itself (Honig and Hirallal 1998; Tout et al. 2005). Teachers who majored in ECE/CD were found to be more socially and emotionally responsive to children and provide more learning activities and materials than those who did not (Howes et al. 2003; Pianta et al. 2005). This may be the case since teachers majored in ECE/CD are likely to have educational experiences that provide a strong knowledge base in child development and effective classroom skills which assist them to provide high-quality classroom experiences (National Research Council 2001).

Another component of teacher qualifications, teaching certification or credentials, has also showed a positive link to children's academic outcomes (DarlingHammond 2000; Tout et al. 2005). However, it is not clear whether certified teachers who finished required course completion provide higher-quality classroom practices than teachers who did not. The lack of associations between certification and classroom practices suggests that classroom practices may not be enhanced through obtaining a teaching certification, and the certification-child outcome link may not be causal. The non-causal association might be due to selection factors (Duncan and Gibson-Davis 2006; Duncan et al. 2004; Early et al. 2006). That is, certified teachers would choose to work at a preschool where children with advanced skills and advantageous backgrounds are likely to attend, rather than the teachers would enhance children's outcome by better classroom practices. In this sense, demonstrating pathways of classroom environments may provide evidence of effectiveness of teacher qualifications.

Further issue with certification may lie in the fact that standards for teaching credentials and certifications vary substantially across states. In some cases, teachers must earn a bachelor's degree to be eligible to get a certification, but this is not always true for different kinds of credentials, resulting in complex associations among certification, education level, and major. This suggests that studies of teacher certification may need to consider other teacher education variables of formal education level and major.

Teaching experience has also been extensively studied as a possible predictor of classroom quality and children's outcomes. A meta-analysis found that teaching experiences predicted children's outcomes, but with a small effect size (.17; Greenwald et al. 1996). However, associations between teaching experiences and classroom quality have been shown to be equivocal. Connor et al. (2005) found 
that teachers with fewer years of teaching experience appeared to be warmer and more responsive in interacting with children than did teachers with more years of experience when teachers' education level was controlled in the analysis. Other studies found that teaching experience was not related to supportiveness in the classroom (e.g., NICHD-ECCRN 2002c).

Recent large-scale studies have examined multiple forms of teacher qualifications in early childhood settings (e.g., Early et al. 2006, 2007). These large-scale studies reported a minimal predictability of teacher qualifications for classroom environments and children's outcomes. Specifically, Early et al. (2006) examined teachers' formal education level, major, and credential as part of teacher qualifications and their associations with classroom environment dimensions (i.e., teaching and interactions, provision for learning, and emotional and instructional quality) and children's pre-academic skills in state-funded prekindergarten programs. They found that teachers' education level predicted early math outcome but teachers' major and credentials did not predict any pre-academic skills. Similarly, Early et al. (2007) found non-significant relations among teachers' formal education and major for classroom environments and children's pre-academic skills. While there are some limitations (i.e., not all indicators of teacher qualifications considered such as teaching certification or teacher experiences in Early et al. 2007), their results suggest that predictability of teacher qualifications may depend on indicators considered in the analysis. These findings suggest that some forms of teacher qualifications can be more likely to be linked to classroom quality and/or children's school readiness than others (Burchinal et al. 2002; Connor et al. 2005) with possible, complex associations among them (e.g., credentials or ECE/CD specialization often requires a bachelor's degree).

Given the associations among teacher qualification indicators and their uneven associations with classroom and children's outcomes, further explorations are needed regarding how each indicator of teacher qualifications uniquely contributes to classroom environments and children's outcomes with multiple indicators considered simultaneously. Previous literature also suggests a need to examine the link between teacher qualifications and children's outcomes rigorously by studying mechanisms/processes that teacher qualifications works through classroom environments (Vandell and Wolfe 2000) to avoid a possibility of spurious predictability of teacher qualifications due to selection factors (Duncan and Gibson-Davis 2006; Early et al. 2006). Further, limited predictability of some indicators of teacher qualifications may imply the role of other types of professional development in improving classroom environments and children's outcomes. Specifically, for children's school readiness outcomes, general teaching experiences or certification may not have a substantial influence; ongoing and explicit training for classroom practices would be more likely to contribute to school readiness.

The Role of In-Service Training in Classroom Environments and Children's Outcomes

In-service training is defined as facilitated teaching and learning opportunities which teachers receive after they enter the workforce (Buysse et al. 2009). These kinds of informal training or education opportunities may work as a supplementary or alternative pathway to formal education and degrees, to the improvement of teachers' classroom practices and children's outcomes (Burchinal et al. 2002; 
Fulligni et al. 2009). There are at least two forms of in-service training that commonly take place outside of formal education and credentialing systems: specialized training and coaching (Buysse et al. 2009). While each form of in-service training may offer a set of widely varying experiences, specialized training often takes the form of episodic workshops, conferences, and lectures and presentations on specific topics, such as curriculum or assessment, and provides teachers with instructions and contents to promote their specific knowledge and skills acquisition (Epstein 1999; Tout et al. 2005); coaching mostly occurs through the process of observation, feedback, demonstration, and self-reflection (e.g., Dickinson and Caswell 2007; Howes et al. 2003; Wasik et al. 2006) and helps teachers interactively learn knowledge and skills and apply them to their own classroom practices in a highly individualized way, tailoring knowledge to fit the situation, needs, and learning styles of each class (Jacobs 2001).

Many early childhood programs offer opportunities for their teachers to attend specialized training (Guskey 2003). Head Start also requires teachers to attend at least $15 \mathrm{~h}$ of intensive specialized training annually (Administration for Children and Families 2007). These specialized trainings seem to make a positive contribution to classroom practices. A recent meta-analysis of 17 quasi-experimental studies demonstrated that specialized training of early childhood caregivers on interaction skills with children had a positive effect on teachers' classroom practices with a medium effect size (Fukkink and Lont 2007). Burchinal et al. (2002) also found that one kind of specialized training, teachers' workshop attendance, made a unique contribution to teachers' sensitive interactions with children. This was true even after controlling for teachers' years of experience, teacher-child ratio, and types of classrooms (i.e., infant-toddler or preschool), but other formal education backgrounds were not considered. Children whose teachers attended workshops and conferences more often displayed more advanced language skills than children whose teachers did not. Like these results, specialized training seems to be linked to improved classroom practices, but it is not clear whether the contribution of specialized training to the quality of classroom environments would be extended to children's outcome even after pre-service training and qualifications are considered in the study.

Recently, another form of in-service training, coaching, has been spotlighted as an intensive professional development to enhance early education classroom practices (Howes et al. 2003). Coaching has been used in intervention programs to improve classroom practices and children's development in discrete domains, such as language and early literacy practices (e.g., Dickinson and Caswell 2007; Neuman and Cunningham 2009; Powell et al. 2008; Wasik et al. 2006), early math practices (e.g., Rudd et al. 2009), or social or emotional practices (e.g., Raver et al. 2008; Webster-Stratton et al. 2001). In addition to discrete instruction-or curriculum-focused coaching, coaching about involving parents in the classroom also enhanced teachers' practices of parent involvement (Hoover-Dempsey et al. 2002). Previous findings posit that coaching can lead to better classroom practices and work effectively as a professional development model (Jacobs 2001).

The existing literature has demonstrated the overall impact of in-service training on teachers' classroom practices. However, there are some limitations in the evidence. First, compared to teacher qualifications studies, there are not many rigorous studies examining the influence of in-service training on children's outcomes. 
Second, most of these studies on in-service training focused on either specialized training or coaching, and did not compare across multiple forms of in-service training. Third, teacher qualifications, including formal education, major, certification, and experience, have not been considered while the pattern or extent of inservice training may be associated with teachers' formal education backgrounds (Burchinal et al. 2002). In this regard, it would be useful to consider various forms of in-service training, specialized training and coaching, along with indicators of teacher qualifications, and examine their unique contributions to classroom environments and children's outcomes, in the broad context of professional development (Fulligni et al. 2009).

\section{Classroom Environment as a Process to Children's School Readiness}

An accumulating body of research has established a link between the quality of early care and education and children's development in language, cognitive, attention, and pre-academic skills as well as social and emotional skills (Curby et al. 2009; Mashburn et al. 2008; NICHD-ECCRN 2002a, b, c, 2003; Peisner-Feinberg et al. 2001). Quality of early care and education has traditionally been viewed as having two primary aspects: structure aspect (i.e., quality aspect that can be regulated, such as teacher qualifications, training, group size, and classroom space) and process aspect (i.e., quality aspect that leads to the direct experiences of children, such as the characteristics of interactions or the use of educational activities and materials) (NICHD-ECCRN 2002a; Peisner-Feinberg and Yazejian 2010). According to NICHD-ECCRN (2002a) and Vandell and Wolfe (2000), process or proximal variables of early care and education quality may be more directly and strongly related to children's outcomes, whereas structure or distal variables may be indirectly associated with children's outcomes through process variables. Thus, in order to investigate a relation between professional development and children's school readiness, we need to focus on how the structure aspect of quality would lead to changes in the process aspect of quality that specifically taps on teachers' practices and children's immediate, learning-related experiences in the classroom (i.e., classroom environments).

With the increased interest in pre-academic skills and school readiness, the quality of learning environments or provision for children's learning has been emphasized as a prominent domain (e.g., Connor et al. 2005; Howes et al. 2008; Justice et al. 2008). Given the characteristics of curricula in early childhood education, teachers' provision for learning would include provisions of materials in learning centers for child-directed activities (e.g., sand/water table area for science area, writing table for emergent writing, and books for reading area) as well as specific instructional practices for teacher-directed activities (e.g., teacher read aloud and letter activity, Connor et al. 2006). Another dimension of interest that may target children's social-emotional skills included social-emotional classroom climates (e.g., teachers' sensitivity to children's social-emotional needs, teacher warmth, and classroom management, Burchinal et al. 2010; Dearing et al. 2009; Gerber et al. 2007; Mashburn et al. 2008). Early childhood classroom environments have often been characterized as having these two dimensions of provision for learning and social-emotional climate (Cassidy et al. 2005; Mashburn et al. 2008; Sakai et al. 2003).

Recently, the field of early childhood education recognized the importance of an additional dimension of classroom quality: teachers' parent involvement prac- 
tices, or teachers' willingness to reach out and become more responsive to families (Copple and Bredekamp 2009; Powell 2001; Zellman and Perlman 2006). Teachers' parental involvement practices have been used as a major indicator of quality in multiple statewide quality rating and improvement systems (QRIS; Office of Planning, Research and Evaluation 2010) for early care and education. This trend is based on the research evidence regarding the role that parents' school involvement plays in children's learning and development (e.g., Epstein 2001; Hill and Craft 2003; Rimm-Kaufman et al. 2003). When parents are involved in their young children's classroom and school, their children seem to have better pre-academic skills and social skills through higher levels of motivation and more positive approaches to learning (Fantuzzo et al. 2004; Powell et al. 2010). In addition, parents are more likely to be involved in classrooms when teachers provide diverse opportunities and connection points for parents to be involved (Hindman and Morrison 2011; McWayne et al. 2008; Powell et al. 2010). Teacher's parental involvement practices may work as an important indicator of classroom environment, particularly for Head Start programs. Head Start has emphasized parental involvement as one of their core services (Powell 2009) and as a major element of their performance standards (Administration for Child and Families 2013).

Provision for learning, social-emotional practices, and parental involvement practices would represent classroom quality indicators for Head Start programs. Further, these three indicators seem to adequately characterize classroom practices that target three major components of school readiness skills, that is, cognitive competencies, social skills, and approaches to learning (McWayne et al. 2004). These process or proximal classroom quality indicators would be enhanced by structural or distal factors of teacher qualifications and in-service training. Classroom quality indicators would work as pathways to enhance children's school readiness (Vandell and Wolfe 2000) and may make causal inference of professional development-child outcome links relatively easier (Duncan and Gibson-Davis 2006).

\section{Current Study}

There has been substantial amount of studies documenting the associations among teachers' qualifications and in-service training, classroom environments, and children's school readiness. However, given the current need to improve school readiness skills of at-risk children and given the unique contextual features of Head Start programs (e.g., characteristics of children and families, requirement for teacher qualification, funding sources, a variety of services provided to children and families), it will be important to look at detailed associations among these elements in the Head Start context.

Thus, our study aimed to consider multiple forms of teacher qualifications (e.g., education, major, experiences, and teaching certification) and in-service training (e.g., specialized training and coaching) (Buysse et al. 2009), and to examine the predictability of these multiple forms for classroom environments (i.e., provision for learning, social-emotional practices, and teachers' parent involvement practices) and children's school readiness (i.e., pre-academic and social skills). Our specific research questions are (1) which form of teacher qualifications and in-service training would be significantly related to Head Start classroom quality and (2) which form of teacher qualifications and in-service training would be significantly linked to Head Start children's school readiness skills. In studying these ques- 
tions, we were interested in (3) pathways through which teacher qualifications and in-service training would predict children's school readiness. Specifically, we examined direct versus indirect links to school readiness through classroom environments (NICHD-ECCRN 2002a). By examining indirect pathways through classroom environments, we expected to approach causal inference of teacher qualifications-child outcome links (Duncan and Gibson-Davis 2006).

Based on the previous literature, we hypothesized that (1) teaching qualifications and in-service training of Head Start teachers would be associated with classroom environments. Among teaching qualifications, teachers' educational backgrounds in higher education and ECE/CD major were hypothesized to have a stronger association with classroom environments than teaching certification and experiences (Pianta et al. 2005; Tout et al. 2005). Within in-service training, coaching was hypothesized to have a stronger association with classroom environments than specialized training (Howes et al. 2003; Jacobs 2001). We also hypothesized that (2) Head Start teachers' qualifications and in-service training would be related to children's school readiness and that (3) it is mostly indirectly through classroom environments (NICHD-ECCRN 2002a; Vandell and Wolfe 2000). Provision for learning would be related to children's pre-academic outcomes, and socialemotional practices would be related to children's social outcomes (Mashburn et al. 2008). Teachers' parent involvement practices were hypothesized to be associated with children's social outcomes (Powell et al. 2010).

\section{Method}

The current study is a secondary data analysis investigation using the data from the Head Start Family and Child Experiences Survey (FACES) 2003. FACES is a part of Head Start's Performance Measures Initiative to examine the effects of Head Start programs on children's outcome and families' well-being (Administration for Children and Families 2008b). FACES 2003 is the recent public FACES cohort data with item-level classroom quality information available. We used data of 3-and 4-year-old children from the entry to Head Start in fall 2003 through their program experiences measured in spring of 2004. Human subject protection procedures were followed throughout the collection of the original data and the secondary analysis.

\section{Participants}

The FACES 2003 study consisted of a nationally representative sample of 2,457 first-year Head Start children who were 3- and 4 years old as well as their parents and teachers in 63 Head Start Programs. These children and programs were randomly selected from a five-step stratified national probability sample using the Head Start Program Information Report file in 2002-2003. First, programs were stratified by three variables: region of the country (northeast, midwest, south, or west); urbanicity (urban vs. rural); and the proportion of minority population in the program (Administration for Children and Families 2008b). Second, 63 programs were selected from stratified sampling, and, third, 175 centers within these 63 programs agreed to participate in the study. In the fourth stage, three classes were selected from each center, resulting in 337 classrooms. Finally, nine children per classroom were selected. Among them, 2,457 children in 337 classrooms whose parents consented were included in the data collection (Administration for Child- 
Table 1 Demographic information of study participants

Variables

Child $(N=2,159)$

Gender

Boy

Girl

Home language

English

Spanish

Others

Ethnicity

$\begin{array}{ll}\text { European-American } & 619 \\ \text { African-American } & 747\end{array}$

Latino-American 675

Others

Maternal education level

Less than high school

High school

Some college/associate degree

BA

Beyond BA

Teacher $(N=310)$

Teaching certificate

Yes

No

Formal education level

High school

Some college/associate degree

BA

Beyond BA

ECE/CD field of education

Yes

No

Years of teaching experience
1,003

1,059

46.5

49.1

61.4

28.2

4.4

28.7

34.6

31.3

27

657

750

456

61

19

115

192

20

178

86

24

196

25

$\mathrm{M}=12.14$
37.1

61.9

6.5

30.4

34.7

21.1

2.8

.8

57.4

27.7

7.7

63.2

8.1

$\mathrm{SD}=8.13$

Percentages of subcategories do not sum to $100 \%$ due to missing data

ren and Families 2008b). For the current analysis, we removed classrooms without observed classroom quality data $(n=27)$ and children without school readiness outcome data $(n=298)$ in spring of the 2003-2004 school year. The final sample of the current study included 2,159 children in 310 classrooms with intact data. Demographic characteristics of children, families, and teachers are presented in Table 1.

\section{Measures}

Teachers' Qualifications and In-Service Training

Participating teachers completed a questionnaire on their demographic characteristics, educational backgrounds, and teaching and training experiences. In terms of their educational backgrounds, teachers reported their formal education, which was recoded into 4 levels $(1=$ high school, 2 = Associate's degree, $3=$ Bachelor's degree, $4=$ Master's degree). Teachers who had an Associate's or higher degree answered wheth- 
er their field of the highest degree was ECE/CD. Teachers were also asked whether or not they had a teaching certificate and how many years of teaching experience they had. Additionally, teachers reported their in-service curriculum-related training: the number of hours of specialized training that they had in the past 12 months and ongoing coaching support. Coaching variable was constructed from combining two specific questions from the teacher report: whether or not they were provided opportunities to observe someone implementing the curriculum and whether or not they had opportunities to be observed and provided feedback on their implementation of the curriculum $(0=n o$ and $1=$ yes; possible range $=0-2)$.

\section{Dimensions of Classroom Environments}

In measuring quality of classroom environments, we utilized individual item scores of classroom observational data with the Early Childhood Environment Rating Scale-Revised (ECERS-R; Harms et al. 2005) and teacher report of their instructional practices in spring 2004, and constructed a summative measure of classroom environment dimensions. The ECERS-R consists of 43 items including physical environments, materials, instructions, interactions, and staff provision. Each item was rated using a 7-point Likert scale where a 1 indicates inadequate, a 3 indicates minimal, a 5 indicates good, and a 7 indicates excellent quality. In addition, teachers rated the frequency of curriculum activities and teaching practices on a 6-point Likert scale $(1=$ never, 2 = once a month or less, $3=$ two or three times a month, 4 = once or twice a week, 5 = three or four times a week, and $6=$ every day).

An exploratory factor analysis of ECERS-R using a principle components analysis with the varimax rotation demonstrated a two-factor structure (i.e., provision for learning and social-emotional practices), which was similar to what previous studies had found (e.g., Cassidy et al. 2005; Sakai et al. 2003). The two factors explained more than $10 \%$ of the total variance. With conceptual and statistical considerations (i.e., considering additional instructional activity items from teacher report and removing some of the items with a low factor loading and/or an itemtotal correlation), the authors reconstructed three dimensions of classroom quality by adding a third factor of teachers' parent involvement practices. Confirmatory factor analysis showed that the three-dimension model has moderate to good fit to the data, $\chi^{2}(d f=776)=1,987.10, p<.001$; IFI $=.78$, CFI $=.78$; RMSEA $=.07$.

Provision for Learning For the dimension of provision for learning, ECERS-R items from the exploratory factor analysis and the teacher report items of instructional activities were reviewed for its conceptual relations. We eliminated items with low correlation with the total items $(r<.20)$. As a result, 13 items (mostly about learning materials, activities, and room arrangement) from ECERS-R and five items of teaching practices from the teacher questionnaire were included as indicators of the dimension of provision for learning. Items include setting learning activities, promoting language activities and encouraging conversations, and teaching literacy skills such as writing and vocabulary (see Table 2 for a list of items). As a measure of provision for learning, mean scores of the items were calculated after each item was standardized. The constructed measure had Cronbach's a coefficient of 84 .

Social-Emotional Practices In order to captuer the dimension of classroom socialemotional practices, which include teachers' warm, supportive, or control behaviors toward children, we reviewed items of the social-emotional practices factor in ECERS-R along with additional items from the sensitivity subscale of the Arnett 
Table 2 List of variables included in quality dimensions

Provision for learning Social-emotional practices

Item ECERS-R

4. Room arrangement for play

15. Books and pictures

16. Encourage child to

17. Language to develop reasoning skills

18. Informal use of language

19. Fine motor

20. Art

21. Music/movement

22. Blocks

23. Sand/water

24. Dramatic play

25. Nature/science

26. Math/numbers

Teacher questionnaire

Learning letter names

Providing writing activities Vocabulary development activities

Reading and conventions

Phonics and rhyming activities

$\begin{array}{ll}\text { CFA } & \chi^{2}=717.977(d f=135) ; \\ \text { fit } & \text { CFI }=.638 ;\end{array}$

indices $\quad$ RMSEA $=.118$

Reliability Cronbach's $a=.835$

\section{ECERS-R}

9. Greeting/departing

31. Discipline

32. Staff-child interactions

33. Supporting interactions among children

CIS Sensitivity subscale

Q1. Speaks warmly to children

Q3. Is attentive when children speak

Q6. Seems to enjoy the children

Q7. Child misbehaves, explain reason

Q8. Encourage child to new experiences

Q11. Enthusiastic about

child's activity

Q14. Pay positive attention to child

Q16. Talk to child on level understand

Q19. Encourage in prosocial behavior

Q25. Kneels, bends to child's level
Parental involvement

practices

Teacher questionnaire

Involve as partners the

strength of curriculum

Parents receive take-home

Parent-teacher conversations

Parents provide input while

volunteering

Parents are committee/

council

Parents are education

advisory committee

Parents are used as resources

Parents provide input on the child assessment

Parents do not have input

in curriculum ${ }^{\mathrm{a}}$

CFA confirmatory factor analysis, ECERS-R Early Childhood Environment Rating Scale-Revised, CIS Caregiver Interaction Scale

a Reverse-coded

Caregiver Interaction Scale (CIS: Arnett 1989). The sensitivity subscale is on a 4 -point-Likert scale $(1=$ not at all, $2=$ somewhat, $3=$ quite a bit, and $4=$ very much), consisting of 10 items to describe teachers' responsiveness, warmth, negative affect and support that occur between teachers and children.

Four items of the ECERS-R factor analysis (e.g., Greeting/departing, Discipline, Staff-child interactions, and Interactions among children) and 10 items of Sensitivity subscale of the CIS were examined for their inter-item reliability. After these items were standardized, item-total correlation was checked and all 14 items were included as indicators (all items have corrected item-total correlation, $r>.20$ ). Mean 
scores of standardized items were calculated as a measure of classroom social-emotional practices. Cronbach's a coefficient of the constructed measure reached .95 .

Parent Involvement Practices Teachers' parent involvement practices was constructed based on 15 items $(0=$ no and $1=$ yes $)$ from the teacher report whether they met individually with parents of all children in their classroom and whether parents provided input on curriculum or child assessment. Out of 15 items, five items with little variability ( $>90 \%$ of response of yes) and one item with low item-total correlation $(r<.20)$ were removed, and the remaining nine items were used to calculate summative scores. Cronbach's a coefficient of the selected nine items was .73.

\section{Children's School Readiness}

Children's school readiness was assessed using three measures of pre-academic skills (e.g., early reading, early mathematics, and receptive vocabulary) and three of social-emotional skills (e.g., social skills, learning behaviors, and approaches to learning). Children's school readiness outcomes, measured in spring 2004, were utilized; initial scores of these measures at the beginning of the 2003 school year were considered as covariates.

Early Reading The Letter-Word Identification Subtest of the Woodcock-Johnson Psycho-Educational Test Battery-Revised (W-J: Woodcock and Johnson 1989) was used as a measure of children's ability to identify letters and words. The Woodcock-Muñoz-Revised Identifcación de Letras y Palabras (Woodcock and MuñozSandoval 1996) was used as a comparable version for children whose primary language was Spanish. W scores of the English and the Spanish version test scores were included for analysis.

Early Mathematics The Applied Problems Subtest of the Woodcock-Johnson Psycho-Educational Test Battery-Revised (W-J: Woodcock and Johnson 1989) was used as a measure of children's ability to analyze and solve numerical and spatial math problems. The Woodcock-Muñoz-Revised Problemas Aplicados (Woodcock and Muñoz-Sandoval 1996) was used as a comparable version for children whose primary language is Spanish. W scores of the English and the Spanish version test scores were included for analysis.

Receptive Vocabulary The Peabody Picture Vocabulary Test, 3rd edition (PPVTIII; Dunn and Dunn 1997) was used as a measure of children's receptive vocabulary. W scores of the test scores were included for analysis. The Spanish version of the PPVT, Test de Vocabulario en Imagenes Peabody (TVIP: Dunn et al. 1986) was not included because the TVIP was normed on a different population and its scores are not equivalent with PPVT scores.

Teacher-Reported Social Skills Teachers were asked to rate 12 items, using a 3-point Likert scale, about how often the child engaged in cooperative interpersonal behaviors (e.g., working well with other children, following teacher's directions). This scale was based on the Personal Maturity Scale (Entwisle et al. 1987) and the Social Skills Rating System (Gresham and Elliott 1990). Cronbach's a coefficient was .88. Summative scores of the total items were calculated.

Teacher-Reported Learning Behaviors The measure used the 29-items Preschool Learning Behavior Scale (PLBS; McDermott et al. 2000), capturing how the child approaches learning tasks and how he/she engages in cooperative classroom behaviors (e.g., showing a lively interest in the activities, carrying out activities according to own ideas rather than in the accepted way). Teachers were asked to rate 
each item on a 3-point Likert scale $(0=$ doesn't apply, $1=$ sometimes applies, and $2=$ most often applies) based on their observations. In the current study, Cronbach's a coefficient was .90 and a summative score of the total items was used.

Parent-Reported Social Skills and Positive Approach to Learning (PSSPAL) The PSSPAL measure attempts to capture children's social interaction skills focusing on cooperative and empathic behaviors and children's approaches to learning such as curiosity, imagination, openness to new tasks and challenges, and positive attitudes toward learning with nine items rated on a 3-point Likert scale $(0=$ not true, $1=$ somewhat/sometimes true, and 2 = very true/often true). The measure was modified from the Entwisle scale of Personal Maturity (Entwisle et al. 1987) and Achenbach Classroom Behavior Checklist (Achenbach et al. 1987). Cronbach's a coefficient was .66, and summative scores were calculated.

\section{Covariates}

Child gender (Matthews et al. 2009), age (Crone and Whitehurst 1999), racial/ ethnic minority status (McLoyd 1998), maternal education (Dearing et al. 2004), and fall initial assessment scores (Connor et al. 2006) as well as home language, that is, whether a child was assessed in Spanish on pre-academic skills (Magnuson et al. 2006), were considered as covariates in prediction of children's school readiness. Final decision of inclusion/exclusion of covariates was described in detail in the preliminary analysis section.

\section{Results}

Analytic Strategy

We examined the relations among early childhood teacher qualifications, inservice training, classroom environments, and Head Start children's pre-academic and social outcomes at the end of the preschool year. We were interested in multiple pathways through which teacher qualifications and in-service training linked to children's outcomes, particularly direct and indirect links through multiple dimensions in classroom environments. Because children were nested within classrooms (i.e., children shared same teachers), children's pre-academic and social skills vary across classrooms. Therefore, to examine whether multi-level analyses are appropriate for the current study, we ran unconditional model of spring children's outcome measures and assessed the significance of the classroom-level variance.

Results from unconditional model from the spring children's outcome measures indicated that all of the outcome measures had statistically significant variance at the classroom level. Classroom-level variance comprised of $30 \%$ of the total variance in receptive vocabulary, $\chi^{2}(d f=309)=1,043.26, p<.001,18 \%$ of the variance in early reading, $\chi^{2}(d f=309)=680.52, p<.001$, and $16 \%$ in early mathematics, $\chi^{2}(d f$ $=309)=659.70, p<.001$. Children's social outcomes were also found to have significant classroom-level variance with $35 \%$ of variance in teacher-reported social skills, $\chi^{2}(d f=309)=1,306.61, p<.001,27 \%$ in teacher-reported learning behaviors, $\chi^{2}(d f=309)=1,024.47, p<.001$, and 4\% in PSSPAL, $\chi^{2}(\mathrm{df}=309)=381.65, p<.01$.

With each child outcome having nesting effects with significant classroom-level variance, we decided to use multi-level path analyses using Mplus (Muthén and Muthén 2010a). Multi-level modeling enables us to obtain accurate standard error estimates by partitioning the variance in children's outcomes into child and classroom sources (Raudenbush and Bryk 2002). 
To strengthen the power of analyses, the Full Information Maximum Likelihood (FIML) estimation of handling missing data was used (Muthén and Muthén 2010b). FIML uses all available data simultaneously in the estimation of a model and produces parameter estimates that are less biased than other procedures for handling missing data (Baraldi and Enders 2010). This enabled us to keep the sample of 2,159 children within 310 classrooms in the analysis. Correlations among the main variables are provided at Table 3. Before computing correlations, we centered variables at a group mean to eliminate the clustering effect of classrooms in correlation coefficients.

\section{Preliminary Analyses \\ Missing Data}

Since our participants include children in classrooms with spring classroom observation data, each classroom has data in at least one dimension of classroom quality. There was no missing data in provision for learning and $1.9 \%$ of classrooms missing data in social-emotional practices and parent involvement practices. Child assessment at the end of school year had missing data ranging from 1 to $7.6 \%$ of participating children. Child racial/ethnic minority status and mother's education level data were missing for 6.7 and $7.3 \%$ of the sample children. Similarly, teacher education variables had less than $4 \%$ of missing data in the classroom level, except for the variable of ECE/CD major (22.3\% missing in the classroom level). The majority of participants did not have missing data for more than $10 \%$ across most variables. Descriptive statistics for all variables from the original data were examined and found similar to the estimates produced using FIML.

\section{Possible Covariates}

To identify possible covariates for our model, we examined the relations of child and family background characteristics to children's pre-academic and social outcomes by including all outcome measures in one multilevel model, where we controlled for classroom clusters. Child's gender and age were identified as significant predictors of all outcome measures. Compared to girls, boys had lower scores on early reading (standardized path coefficient, ${ }^{1} \mathrm{~b}_{\mathrm{Std} Y \mathrm{X}}=-.12, p<.001$ ), early math $\left(b_{\mathrm{Std} Y X}=-.10, p<.001\right)$, receptive vocabulary $\left(b_{\mathrm{Std} Y X}=-.05, p<.01\right)$, social skills $\left(\mathrm{b}_{\mathrm{Std} Y \mathrm{X}}=-.25, p<.001\right)$, learning behavior $\left(\mathrm{b}_{\mathrm{Std} Y \mathrm{X}}=-.24, p<.001\right)$ and PSSPAL $\left(b_{\text {StdYX }}=-.10, p<.001\right)$; older children had higher scores than younger children on all outcome measures, including early reading $\left(\mathrm{b}_{\mathrm{Std} Y \mathrm{X}}=.44, p<.001\right)$, early math $\left(\mathrm{b}_{\mathrm{StdYX}}=.43, p<.001\right)$, receptive vocabulary $\left(\mathrm{b}_{\mathrm{Std} Y \mathrm{X}}=.51, p<.001\right)$, social skills $\left(\mathrm{b}_{\mathrm{St}-}\right.$ $\mathrm{dYX}=.28, p<.001)$, learning behaviors $\left(\mathrm{b}_{\mathrm{Std} Y \mathrm{X}}=.24, p<.001\right)$ and PSSPAL $\left(\mathrm{b}_{\mathrm{Std} Y \mathrm{X}}=\right.$ $.12, p<.001)$. Children with a racial/ethnic minority status had significantly lower scores than European American children on early math $\left(b_{\mathrm{StdYX}}=-.13, p<.001\right)$ and receptive vocabulary $\left(b_{\mathrm{Std} Y \mathrm{X}}=-.15, p<.001\right)$, but not on other outcome measures $\left(b_{\text {StdYX }}=-.02,-.01, .02\right.$, and .04 for early reading, social skills, learning behavior, and

${ }^{1}$ Standardized path coefficients reported here calculated with the StdYX option in the Mplus, which uses the variances of the continuous latent variables as well as the variances of the background and outcome variables for standardization. This is similar to the one used in the linear regression of $y$ on $x, b_{S t d Y X}=b^{*} S D(x) / S D(y)$, but in the context of multiple-level path modeling using FIML. For convenience of reporting, we used $b_{S t d Y X}$ here as a notation for standardized path coefficients. 


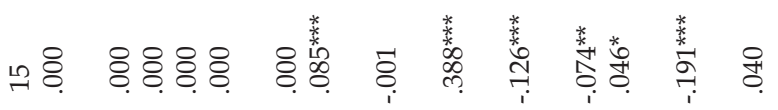

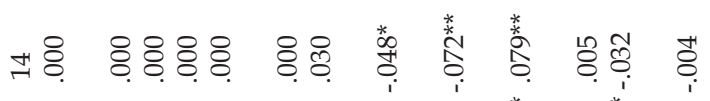

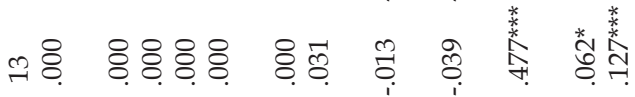

요.

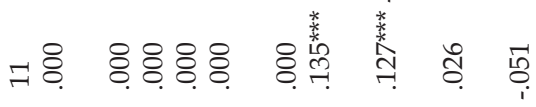

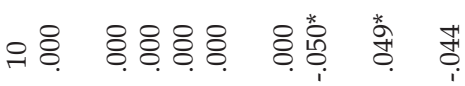

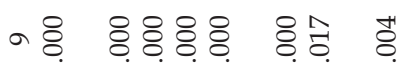

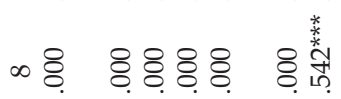

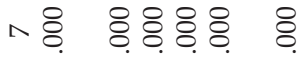

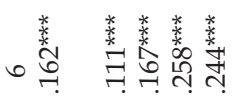

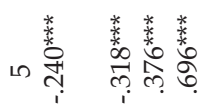

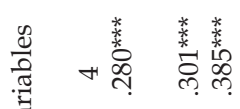

要的憘喜

苞

0
0
0
0
0
0
0
0
0
0
0
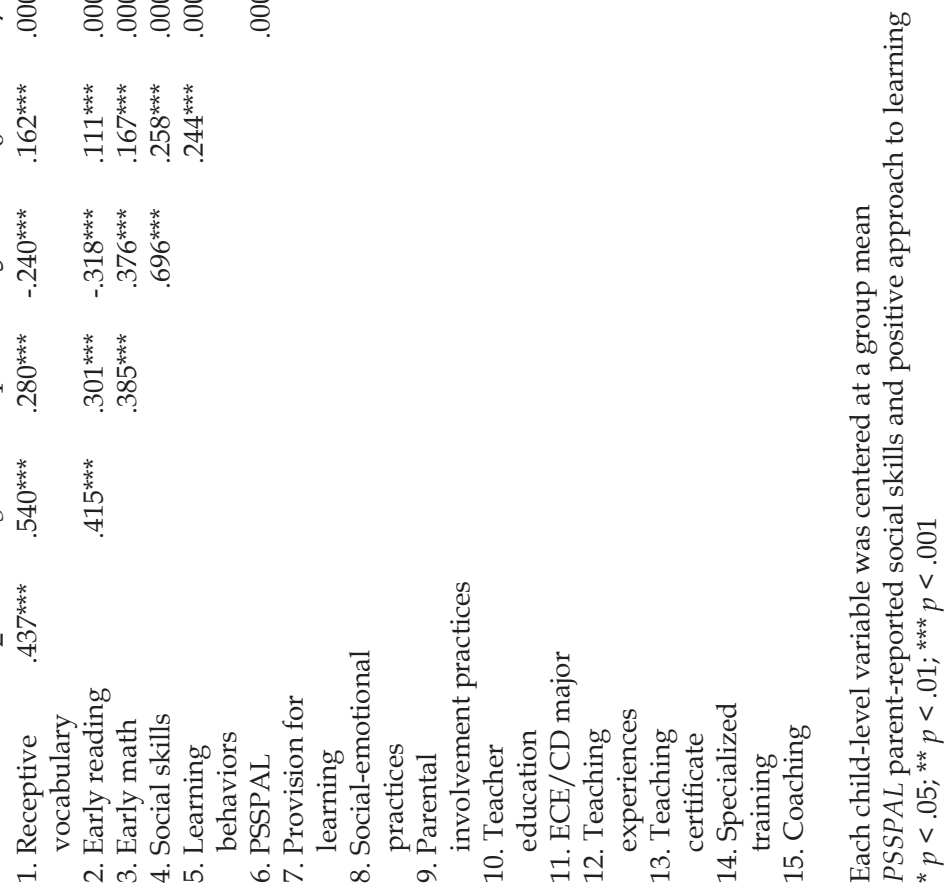
PSSPAL, respectively). Children who took the Spanish-version test received lower scores in early math $\left(b_{\mathrm{Std} Y \mathrm{X}}=-.07, p<.001\right)$ than those who took the Englishversion test and there was no significant difference between children taking the Spanish-version versus the English-version early reading assessments. Finally, the mother's education was a significant predictor of early reading $\left(b_{\mathrm{StdYX}}=.15, p<\right.$ $.001)$, early math $\left(\mathrm{b}_{\mathrm{StdYX}}=.16, p<.001\right)$, receptive vocabulary $\left(\mathrm{b}_{\mathrm{Std} Y \mathrm{X}}=.17, p<.001\right)$ and PSSPAL $\left(\mathrm{b}_{\mathrm{Std} Y \mathrm{X}}=.10, p<.001\right)$, but not social skills or learning behaviors.

In deciding final covariates, we considered a set of covariates consistently across equations of pre-academic outcomes and another set of covariates consistently across equations of social outcome. As a result, child gender, age, racial/ethnic minority, mother's education, and Spanish assessment indicator were included as covariates in equations modeling pre-academic outcomes, and child gender, age, and mother's education were covariates in equations modeling social outcomes. Children's initial skill levels measured in the fall of the preschool year were considered as a covariate for every outcome measure.

\section{Building the Final Model}

To assess the unique relation of Head Start teachers' qualifications and in-service training to classroom environments and children's school readiness at the end of preschool year, we simultaneously examined the contributions of teacher qualifications and in-service training variables to multiple aspects of classroom environments and children's outcomes as a multi-level path model. Children's school readiness was predicted by three dimensions of classroom environments and also linked to teacher qualifications and in-service training variables controlling for covariates; and classroom environments were predicted by teacher qualifications and in-service training variables. All of the six children's outcomes were included simultaneously in one model to control for covariance among them. Since unbiased estimates of the coefficients of classroom-/teacher-level variables were the substantive interest of the current study, we centered all predictors at the grand mean (Enders and Tofighi 2007). In the path model, classroom-level variance (i.e., random effect) was tested for the coefficient of children's outcomes and classroom quality (i.e., intercept).

We originally considered children's initial assessment of each outcome measure as a possible covariate; however, due to a short time gap between assessments $(\mathrm{M}=$ 5.60 months; $\mathrm{SD}=.87$ months), the two scores were highly associated; standardized path coefficients of initial scores predicting later scores ranged from .50 to .66 (all $p^{\prime} \mathrm{s}$ $<.001)$ in the multi-level modeling. The model did not have a good fit, $\chi^{2}(d f=138)=$ $5,130.17, p<.001$, comparative fit index $(\mathrm{CFI})=.60$, root mean square error of approximation $($ RMSEA $)=.13$, and standardized root mean square residual (SRMR) for level $1=.15$ and for level $2=.08$. We reran the model after removing the initial assessment from the covariates list and the model fit improved, $\chi^{2}(d f=63)=442.97, p<.001, \mathrm{CFI}$ $=.92$, RMSEA $=.06$, and SRMR for level $1=.03$ and for level $2=.10$. Path coefficients and their significance results were very similar between the original and revised models. Thus, the revised model was reported as our final model (see Figure 1).

\section{Relations between Teacher Qualifications and In-Service Training on Head Start Classroom Quality}

Teacher qualifications and in-service training variables had unique relations with classroom environment dimensions. Specifically, teachers' ECE/CD major 
was significantly related to social-emotional practices $\left(\mathrm{b}_{\mathrm{Std} Y \mathrm{X}}=.16, p<.05\right)$ as well as provision for learning $\left(\mathrm{b}_{\mathrm{Std} Y \mathrm{X}}=.17, p<.05\right.$; see Table 4$)$. By controlling for all teacher qualifications and in-service training variables, the education level itself was not a predictor of any classroom environment dimension. Similarly, teaching certification and years of teaching experiences were not significant predictors of the classroom environments, either. Among in-service training variables, coaching predicted classroom environments. Specifically, coaching was a significant predictor of provision for learning $\left(\mathrm{b}_{\mathrm{StdYX}}=.12, p<.05\right)$ and teachers' parent involvement practices $\left(b_{\text {StdYX }}=.40, p<.001\right)$; however, hours of specialized training did not predict any of classroom environment dimensions.

Relations between Teacher Qualifications and In-Service Training on Head Start Children's School Readiness

The final model demonstrated no significant direct paths to children's outcome except a path from teachers' education level to early reading $\left(b_{\mathrm{Std} Y \mathrm{X}}=.22, p<\right.$ .05). In other words, children had higher scores in early reading only when their teach ers had higher education levels, irrespective of the quality of teacher's classroom environment/practice. Results indicated that children's outcomes, except early reading, tended to be indirectly influenced by teacher qualifications or inservice training variables through classroom environments. Head Start teachers who had majored in ECE/CD provided higher-quality social-emotional practices than those who did not, and children enrolled in higher-quality social-emotional

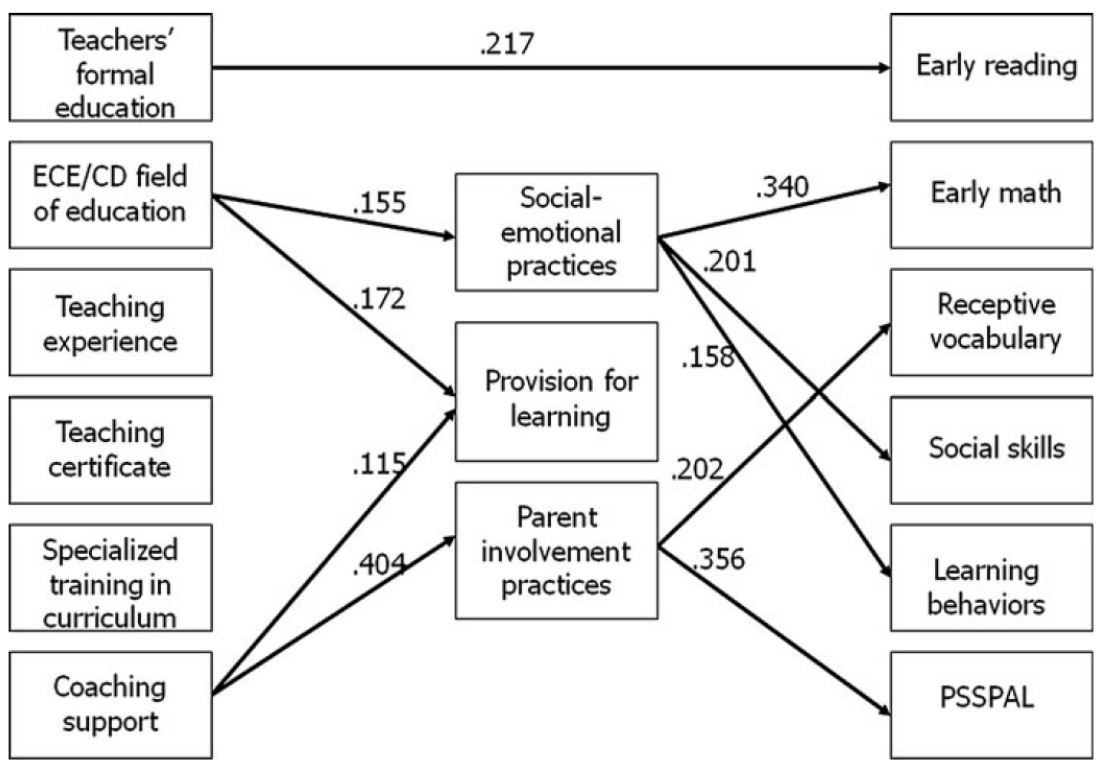

Figure 1 Two-level path analysis of teacher qualifications and in-service training effects. Note: ECE/CD early childhood education/child development, PSSPAL parent-reported social skills and positive approach to learning. Only significant paths were included. $\chi^{2}(d f=63)$ $=442.97(p<.001)$, CFI $=.92$, RMSEA $=.06$, standardized root mean square residual (SRMR) level $1=.03$; level $2=.10$ 


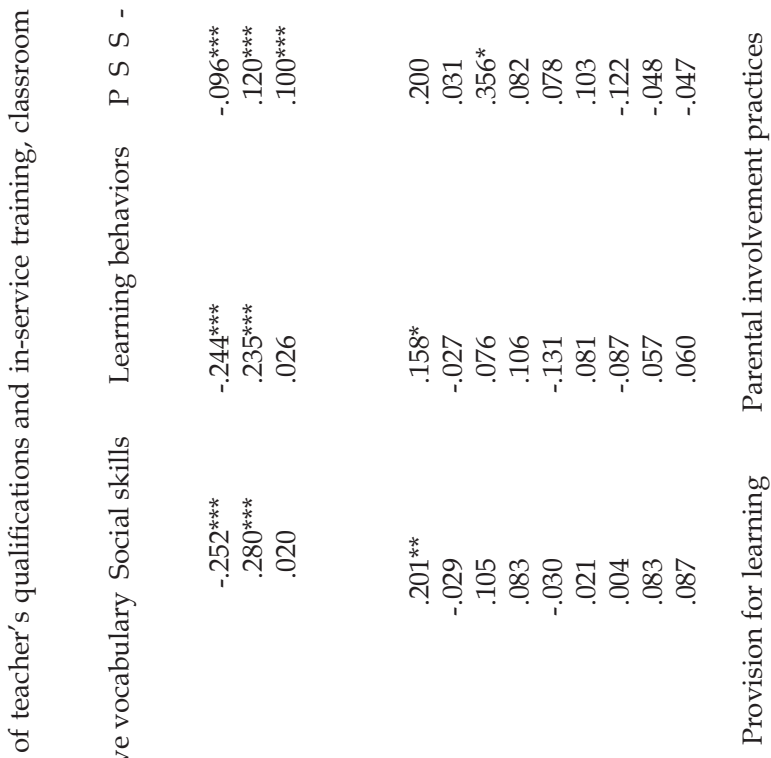

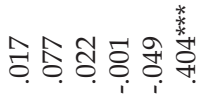

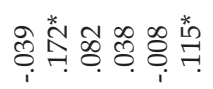

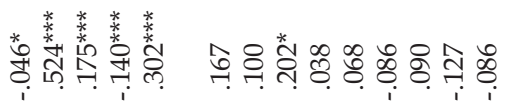

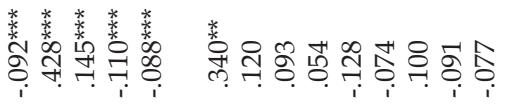

0
0
0
0
0
0
0
0
0
0
0
0
$\frac{1}{0}$
0
0
0

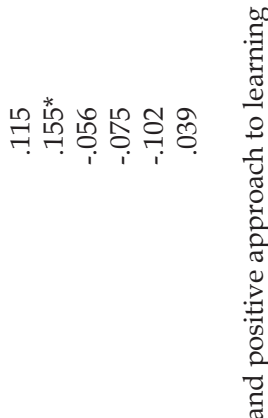

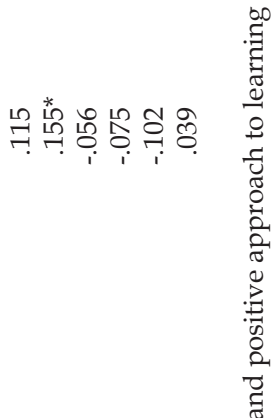

:

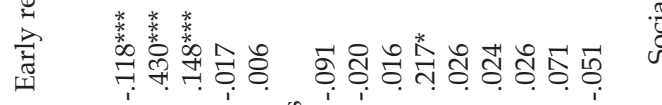

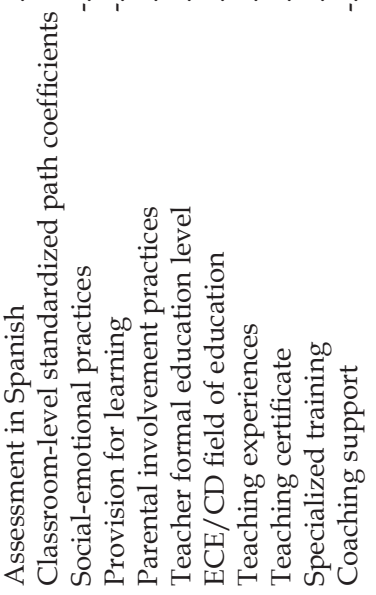

至

?ृ.

:

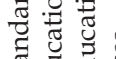

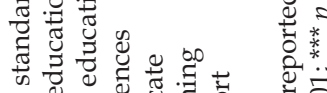


classrooms demonstrated higher scores on social skills $\left(\mathrm{b}_{\mathrm{Std} Y \mathrm{X}}=.20, p<.01\right)$, learning behaviors $\left(\mathrm{b}_{\mathrm{Std} Y X}=.16, \mathrm{p}<.05\right)$, and early math skills $\left(\mathrm{b}_{\mathrm{Std} Y X}=.34, p<.01\right)$ than those in lower-quality social-emotional classrooms. The link of teacher ECE/CD major to children's outcomes through social-emotional practices was significant with a standardized indirect effect of $.081(p<.01)$ for early math skills, but not for social skills or learning behaviors (see Table 5). The provision for learning was not a predictor of children's outcomes even though Head Start teachers who had majored in ECE/CD and who received coaching support provided higher-quality provision for learning than those who did not.

Finally, coaching was positively associated with teachers' parent involvement practices, which was in turn linked to children's higher scores on PSSPAL $\left(\mathrm{b}_{\mathrm{StdYX}}=.36, p<\right.$ $.05)$ and receptive vocabulary skills $\left(\mathrm{b}_{\mathrm{Std} Y \mathrm{X}}=.20, p<.05\right)$. These specific indirect paths were both statistically significant with standardized indirect effect sizes of .155, $p<.05$ and .100, $p<.01$ (see Table 5). Overall, teachers' education and training variables had a respectively small total effect especially on PSSPAL and receptive vocabulary, but the total effects of ECE/CD major and coaching support on classroom environments were significant, which were then positively linked to children's school readiness outcomes.

\section{Discussion}

Our current study attempted to provide a comprehensive picture of the role that teacher qualifications and in-service training play in early childhood classroom environments and school readiness of low-income children in Head Start. Specifically, this study examined (1) multiple indicators of teacher qualifications, including the education level, ECE/CD major, teaching certification, and years of teaching experience and (2) teachers' in-service training experiences including hours of specialized training and coaching, as factors related to (3) multiple aspects of Head Start children's school readiness, including pre-academic and social competences, through (4) multiple dimensions of classroom environments that include teachers' provision for learning, social-emotional practices, and parent involvement practices. Due to the nature of correlation study, the findings cannot be interpreted causally. However, the current study used appropriate statistical controls to calculate reliable estimates of associations among study variables by (5) considering nesting of children within classrooms with multi-level modeling as well as controlling for a set of background factors (6) with a nationally representative sample of Head Start children. Further, the current study utilized (7) pathways modeling to examine indirect mechanisms of professional development-classroom environmentschild outcome links to minimize selection bias. Given the primary goal of Head Start programs on children's school readiness (U.S. Department of Health and Human Services 2010) and the recent evidence on the importance of high-quality classroom for at-risk children (Logan et al. 2011), it seems particularly critical and timely for the current study to addresses the topic of professional development as predictors of quality education for low-income children's school readiness.

Table 5 Standardized total effects (and total indirect effects) for the final model

The Importance of Teacher Qualifications in Classroom Quality and Children's School Readiness

The current study confirmed our hypothesis that some components of teacher qualifications, especially their educational background, were associated with 


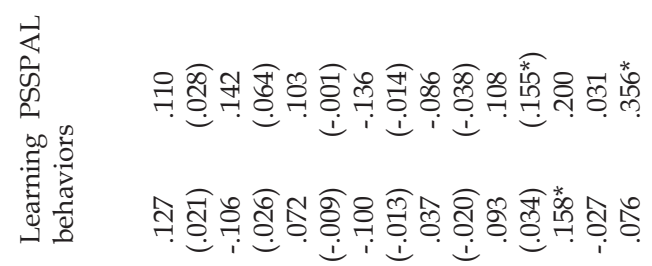

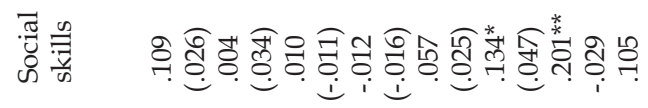

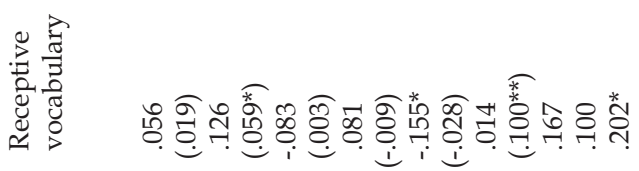

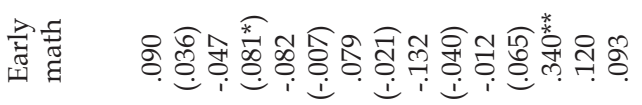

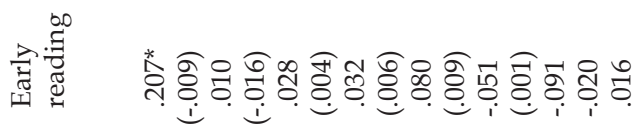

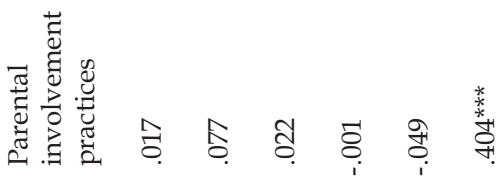

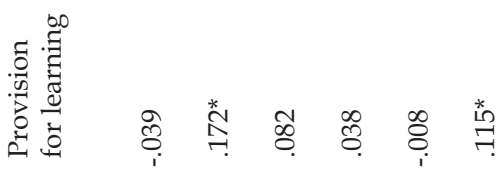

II

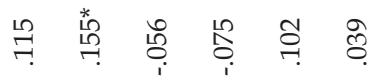

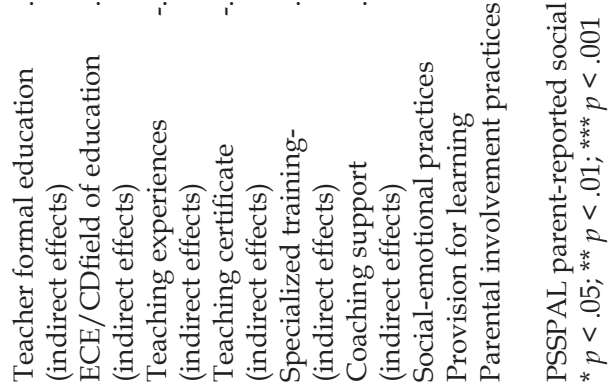


Head Start children's school readiness. However, the patterns of associations varied across components. First, teachers' education level was uniquely and directly associated with children's early reading skills at the end of school year. However, teachers' education level did not indirectly predict early reading through proximal classroom environments, which is opposed to our theoretical framework (NICHDECCRN 2002a). While teachers who had a higher education level may have more literacy-related knowledge, skills, and expectations that could influence children's early reading skills directly, the process through which teachers' education level explicitly contributes to children's early reading is not clear. It is likely that the association may be due to other selection factors (i.e., endogeneity bias, Duncan et al. 2004) that teachers with lower educational levels tend to work in programs with children with substantially disadvantaged backgrounds and lower reading skills (Early et al. 2006; Peske and Haycock 2006). It would also be possible that our measures on classroom practices are not sensitive enough to capture teachers' skills and related knowledge at least for the Head Start classrooms in the current study.

Second, teachers' ECE/CD major predicted children's school readiness indirectly through classroom environments. Specifically, teachers who majored in ECE/ CD provided higher quality social-emotional practices, which were in turn related to Head Start children's early math and teacher-reported social skills and learning behaviors. Results suggest that not just formal education level, but also specific training/majoring in ECE/CD, including courses that address child development and developmentally appropriate care and education along with practicum experiences (Early and Winton 2001), would lead to teacher preparation for real classroom actions for school readiness. These well-prepared teachers would provide more sensitive and responsive classroom environments that lead to better school readiness for children at risk for school failure (Burchinal et al. 2010; Dearing et al. 2009).

Our finding about the ECE/CD major is consistent with that of Pianta et al. (2005). Pianta and his colleagues found that state-funded pre-kindergarten teachers' BA degree in ECE/CD was meaningfully associated with the classroom's emotional climate and provision for learning. However, these results are inconsistent with those of Early and her colleagues' research (Early et al. 2006, 2007), which did not find relations between teachers' ECE/CD major and their set of classroom environments dimensions. As discussed earlier, Early et al.'s study (2006) did not consider other teacher qualification variables, such as years of teaching experience in their analysis. Early et al. (2007) utilized global quality of classroom environments using the total scores of the ECERS-R, which may have masked the links of ECE/CD major to specific dimensions of classroom environments. Besides, Early et al. (2007) did not account for classroom-level variability (i.e., classroom nesting) in their analysis.

Lastly, other indicators of teacher qualifications, teaching certification, and teaching experience did not significantly predict any of the classroom environment dimensions or children's outcomes. This may suggest that simply requiring more experiences and teaching certification would not be a route to higher quality educational experiences and children's school readiness. However, the non-significance of teaching certification would not be easy to interpret with the variation of certification/credentialing structure across states. Without investigating detailed contents of certification structure, it would not be possible to know whether the current result is due to the effectiveness of certification itself or due to certification structure. 
The Role of Teachers' In-Service Training in Classroom Quality and Children's School Readiness

The study confirms that Head Start teachers would benefit from receiving in-service training that provides support for skills to form effective classroom processes for school readiness (Burchinal et al. 2002; Dickinson and Caswell 2007; Powell et al. 2008; Wasik et al. 2006). Specifically, one-on-one, individualized, and ongoing coaching support, rather than specialized training (i.e., one-day group workshop), can be more effective training methods to help teachers improve their practices of discrete curriculum areas (i.e., provision for learning) or class organization strategies (i.e., parent involvement practices). The current study extended the previous literature by examining predictability of different forms of teachers' in-service training over and beyond teacher qualifications for Head Start teachers.

Coaching provides opportunities to observe other teachers' classrooms and receive feedback on what teachers do in their own classroom, thus addressing unique needs and issues that each class has (e.g., Howes et al. 2003; Wasik et al. 2006). These opportunities would provide teachers with strategies and resources directly applicable to their provision for children's learning as well as to involve and utilize parents as teaching resources and collaborators. The association between coaching support and parent involvement practices would make one of the unique findings of the current study. Results showed that teachers' parental involvement practices led by coaching support uniquely predicted low-income children's vocabulary and approaches to learning. A possible interpretation of these associations includes, ongoing coaching support might help teachers become more confident in their classroom practices, thus they may be more likely to reach out to parents and involve them in classroom instructions (Howes et al. 2003). In doing so, teachers could encourage parents to become active participants in their children's learning and promote children's engagement in learning and school readiness (Hindman and Morrison 2011).

Our results confirm the importance of one of the goals in Head Start programs: improving school readiness through having positive impacts on parenting (Office of Head Start 2011), especially in the context of working with at-risk families (Cooper et al. 2010). As Head Start programs serve families with diverse backgrounds (Hoover-Dempsey et al. 1992), extra support for Head Start teachers, such as coaching, to work effectively with those families would be critical for children's learning and school readiness, especially social skills and approaches to learning. The results suggest that teachers' parent involvement practices warrant further consideration as a potentially distinct dimension within classroom environments, especially for Head Start classrooms.

Lastly, it is worth noting that although teachers' ECE/CD field of education and coaching contributed to their classroom provision for learning, provision for learning was not associated with any of children's outcomes. In contrast, teachers' social-emotional practices associated with the ECE/CD field of education predicted children's math outcomes. Our speculations include that providing enriched learning opportunities and environments may not suffice to improve school readiness of low-income children's school readiness without teachers' instructional strategies to address specific curriculum contents. Given the generally low developmental skills that low-income children tended to have (Desimone and Long 2010; Sektnan et al. 2010), simple focus on provision for domain-specific cognitive 
learning (e.g., early literacy, math) may not be enough unless it is accompanied by socially and emotionally supportive environments that may target domaingeneral cognitive and social skills (e.g., self-regulation, classroom behaviors) (Fantuzzo et al. 2007; McClelland and Wanless 2012). Other considerations may include weaknesses of the current measure of provision for learning. The measure of provision for learning attempted to capture a traditional curriculum focus in early childhood education (e.g., provisions of learning environments, centers, and materials; Dodge et al. 2002), without clearly representing the quality of teachers' instructional behaviors. Adding more information of teachers' instructional practices and strategies may well represent early childhood classroom environments and will show links to children's school readiness as shown in an existing measure (e.g., CLASS, Pianta et al. 2008).

\section{Implications for Practice and Future Research}

The current study confirmed that teachers' field of education and in-service training matters for classroom quality and children's school readiness in the Head Start context. Furthermore, low-income children's school readiness tends to be associated with multiple dimensions of classroom environments simultaneously, instead of a separate individual dimension of provision for learning.

Based on the research findings, we suggest that Head Start teachers need to have a ECE/ CD major and be provided with further access to ongoing training and coaching support to enhance classroom quality and Head Start children's school success. It is timely to discuss teacher training in the current policy context where there is heightened public awareness of the effect of Head Start programs on children's school readiness and a need for further evidence of how the Head Start programs work. With the Head Start mandate for increased teacher credentials, the current level of teachers' professionalism may be reinforced. In fact, FACES 2003 data demonstrated that Head Start classrooms' global quality and teacher qualifications were improved (Zill et al. 2006). With the Head Start mandate, many teachers tend to concurrently go through multiple forms of professional development including formal education as well as in-service training. The current data might represent resulting increased qualifications of teachers, and provide us an opportunity to examine the effects of changes in professional development.

Our results, specifically, demonstrate the importance of coaching for Head Start teachers in the current policy context. The field of early care and education is beginning to acknowledge the importance or effectiveness of coaching (e.g., Domitrovich et al. 2009); and, there is an urgent need to develop a comprehensive training and support model of coaching for Head Start teachers who have relatively high-level challenges and stresses that result partly from dealing with children with developmental and familial risks (Buscemi et al. 1996). The effectiveness of on-going coaching support compared to specialized in-service trainings could be considered in planning for required staff training in Head Start (i.e., $15 \mathrm{~h}$ a year; Administration for Children and Families 2007). The planning could make sure that teachers have an opportunity to receive sustained and job-embedded individualized support (Darling-Hammond et al. 2009) and use a professional learning community to share their classroom needs and practices through coaching or mentoring programs (Stoll et al. 2006). Given the goals (i.e., promoting school readiness) and unique characteristics of Head Start programs (i.e., low-income 
children, emphasis on parent involvement), in-service training in Head Start programs should be ongoing and intensive, focusing on (a) supporting teachers to create high-quality and well-balanced classroom environments with positive social emotional climate and instructional practices and (b) promoting parent involvement throughout diverse aspects of classroom learning to encourage parents to actively support children's school readiness. The missing link between teachers' provision for learning and children's pre-academic school readiness in the current study may imply a need for teacher training that focuses more on instructional strategies to address specific curriculum contents in addition to providing classroom environments and materials. This is also reflected in the recent addition to the National Association for the Education of Young Children (NAEYC)'s professional preparation standards (i.e., using content knowledge to build meaningful curriculum; NAEYC 2009).

Despite the extensive scope of the data used in the current study, the data did not provide any specific contents or elements of teacher education and in-service training in detail. For example, while coaching has been demonstrated as an effective form of professional development, it is not clear what aspects within coaching support would make a major contribution to classroom practices and children's school readiness. Coaching support usually includes job-embedded, sustained, substantial, reflective, and collaborative learning, each of which has been suggested as effective elements of professional development (Darling-Hammond et al. 2009). However, there is a paucity of rigorous studies that directly manipulate and examine the contribution of these 'elements' of professional development, beyond the 'forms' or 'types' of professional development. Future studies need to consider more detailed measures of professional development, including its contents, targets, intensity as well as characteristics of educators and coaches. The detailed examination could provide evidence about the links between various elements of teacher training and classroom and children's school readiness and lead to a design of successful professional development.

In order to target and evaluate classroom practices and quality improvement in early care and education settings, there is a call for specified measures to capture multidimensional classroom environments, focusing on classroom practices or behaviors that are proximal to children's outcomes. This is especially true for provision for learning. The current measure focusing on 'learning environment' may represent the traditional curricula focus in early childhood education, which may be a likely target of coaching given the significant association between coaching and provision for learning. However, learning environments and materials may not be as proximal or specific as to teachers' instructional behaviors that may directly lead to changes in children's school readiness. Measures that assess teachers' instructional behaviors as well as provision of environments may tap into the full spectrum of provision for learning.

Finally, program administrators and policy makers need to be aware that lowincome children's school readiness tends to be predicted by multiple dimensions of classroom environments simultaneously, instead of one single dimension of provisionforlearning. Furthermore, theyneed toconsidercomprehensiveways toimprove multiple aspects of classroom environments through utilizing various forms of professional development opportunities that can provide ongoing individualized training and support, in order to ensure better school readiness for low-income children. 


\section{References}

Achenbach, T. M., Edelbrock, C., and Howell, C. T. (1987). Empirically based assessment of the behavioral/emotional problems of 2-and 3-year-old children. Journal of Abnormal Child Psychology 15: 629-650. DOI: $10.1007 /$ BF00917246.

Ackerman, D. J. (2004). States' efforts in improving the qualifications of early care and education teachers. Educational Policy 18: 311-337. DOI: 10.1177/0895904803262145.

Administration for Children and Families. (2007). Head Start Act, 42 USC 9801.

Administration for Children and Families. (2008a). Statutory degree and credentialing requirements for head start teaching staff. ACF-IM-HS-08-12. U.S. Department of Health and Human Services, Office of Head Start.

Administration for Children and Families. (2008b). Head Start FACES 2003 data user's guide. Washington, D.C.: U.S. Administration for Children and Families, Office of Planning, Research and Evaluation.

Administration for Children and Families. (2013). Family partnerships from Head Start program performance standards and other regulations. Retrieved from http:/ / eclkc.ohs.acf.hhs.gov/hslc/standards/Head \%20Start\%20Requirements/1304/1304.40\%20Family\%20partnerships.htm.

Arnett, J. (1989). Caregivers in day-care centers: Does training matter? Journal of Applied Developmental Psychology 10: 541-552. DOI: 10.1016/0193-3973(89)90026-9.

Baraldi, A. N., \& Enders, C. K. (2010). An introduction to modern missing data analyses. Journal of School Psychology 48: 5-37. DOI: 10.1016/j.jsp.2009.10.001.

Barnett,W.S.(2003). Betterteachers, betterpreschools:Studentachievementlinked toteacherqualifications. NIEER Preschool Policy Matters, Issue 2. New Jersey: National Institute for Early Education Research.

Burchinal, M. R., Cryer, D., Clifford, R. M., and Howes, C. (2002a). Caregiver training and classroom quality in child care centers. Applied Developmental Science 6: 2-11. DOI: 10.1207/S1532480XADS0601_01.

Burchinal, M., Hyson, M., and Zaslow, M. (2008). Competencies and credentials for early childhood educators: What do we know and what do we need to know? NHSA Dialog Briefs, Issue 1. Alexandria, Va.: National Head Start Association Research and Evaluation Department.

Burchinal, M. R., Peisner-Feinberg, E., Pianta, R., and Howes, C. (2002b). Development of academic skills from preschool through second grade: Family and classroom predictors of developmental trajectories. Journal of School Psychology 40: 415-436. DOI: 10.1016/S0022-4405(02)00107-3.

Burchinal, M., Vandergrift, N., Pianta, R., and Mashburn, A. (2010). Threshold analysis of association between child care quality and child outcomes for low-income children in pre-kindergarten programs. Early Childhood Research Quarterly 25: 166-176. DOI: 10.1016/j.ecresq.2009.10.004.

Buscemi, L., Bennett, T., Thomas, D., and Deluca, D. A. (1996). Head Start: Challenges and training needs. Journal of Early Intervention 20: 1-13. DOI: 10.1177/105381519602000101.

Buysse, V., Winton, P. J., and Rous, B. (2009). Reaching consensus on a definition of professional development for the early childhood field. Topics in Early Childhood Special Education 28: 235-243. DOI: $10.1177 / 0271121408328173$.

Cassidy, D. J., Hestenes, L. L., Hegde, A., Hestenes, S., and Mims, S. (2005). Measurement of quality in preschool child care classrooms: an exploratory and confirmatory factor analysis of the early childhood environment rating scale-revised. Early Childhood Research Quarterly 20: 345-360. DOI: 10.1016/j.ecresq.2005.07.005.

Caughy, M., DiPietro, J., and Strobino, D. (1994). Day-case participation as a protective factor in the cognitive development of low-income children. Child Development 65: 457-471.

Connor, C. M., Morrison, F. J., and Slominski, L. (2006). Preschool instruction and children's emergent literacy growth. Journal of Educational Psychology 98(4): 665-689. DOI: 10.1037/0022-0663.98.4.665.

Connor, C. M., Son, S.-H., Hindman, A. H., and Morrison, F. J. (2005). Teacher qualifications, classroom practices, family characteristics, and preschool experience: complex effects on first graders' vocabulary and early reading outcomes. Journal of School Psychology 43: 343-375. DOI: 10.1016/j.jsp.2005.06.001.

Cooper, C. E., Crosnoe, R., Suizzo, M.-A., and Pituch, K. A. (2010). Poverty, race, and parental involvement during the transition to elementary school. Journal of Family Issues 31: 859-883. DOI: 10.1177/0192513X09351515.

Copple, C., and Bredekamp, S. (2009). Developmentally Appropriate Practice in Early Childhood Programs Serving Children from Birth through age 8 (3rd ed.). Washington, D.C.: National Association for the Education of Young Children.

Crone, D. A., and Whitehurst, G. J. (1999). Age and schooling effects on emergent literacy and early reading skills. Journal of Educational Psychology 91: 604-614. DOI: 10.1037/0022-0663.91.4.604.

Curby, T. W., LoCasale-Crouch, J., Konold, T. R., Pianta, R. C., Howes, C., Burchinal, M., et al. (2009). The relations of observed Pre-K classroom quality profiles to children's achievement and social competence. Early Education and Development 20: 346-372. DOI: 10.1080/10409280802581284. 
Darling-Hammond, L. (2000). Teacher quality and student achievement: A review of state policy evidence. Educational Policy Analysis and Archives 8: 1-44.

Darling-Hammond, L., Wei, R. C., Andree, A., Richardson, N., and Orphanos, S. (2009). Professional Learning in the Learning Profession: A Status Report on Teacher Development in the United States and Abroad. Stanford, Calif.: National Staff Development Council and the School Redesign Network at Stanford University.

Dearing, E., McCartney, K., and Taylor, B. A. (2009). Does higher quality early child care promote low-income children's math and reading achievement in middle childhood? Child Development 80: 1,329-1,349. DOI: 10.1111/j.1467-8624.2009.01336.x.

Dearing, E., McCartney, K., Weiss, H. B., Kreider, H., and Simpkins, S. (2004). The promotive effects of family educational involvement for low-income children's literacy. Journal of School Psychology 42: 445-460. DOI: 10.1016/j.jsp.2004.07.002.

Desimone, L. M., and Long, D. (2010). Teacher effects and the achievement gap: do teacher and teaching quality influence the achievement gap between black and white and high-and low-SES students in the early grades? Teachers College Record 112: 3,024-3,073.

Dickinson, D. K., and Caswell, L. (2007). Building support for language and early literacy in preschool classrooms through in-service professional development: effects of the Literacy Environment Enrichment Program (LEEP). Early Childhood Research Quarterly 22: 243-260. DOI: 10.1016/j. ecresq.2007.03.001.

Dodge, D. T., Bickart, T. S., Colker, L. J., and Heroman, C. (2002). The Creative Curriculum for Preschool (4th ed.). Bethesda, Md.: Teaching Strategies.

Domitrovich, C. E., Gest, S. D., Gill, S., Bierman, K. L., Welsh, J., and Jones, D. (2009). Fostering high quality teaching with an enriched curriculum and professional development support: The Head Start REDI program. American Educational Research Journal 46: 567-597.

Duncan, G. J., and Gibson-Davis, C. M. (2006). Connecting child care quality to child outcomes: Drawing policy lessons from nonexperimental data. Evaluation Review 30: 611-630. DOI: 10.1177/0193841X06291530.

Duncan, G. J., Magnusson, K. A., and Ludwig, J. (2004). The endogeneity problem in developmental studies. Research in Human Development 1: 59-80. DOI: 10.1177/00113921030515005.

Dunn, L. M., and Dunn, L. M. (1997). Peabody Picture Vocabulary Test (3rd ed.). Circle Pines, Minn.: American Guidance Service.

Dunn, L. M., Lugo, D. E., Padilla, E. R., and Dunn, L. M. (1986). Test de Vocabulario en Imagenes Peabody (TVIP) [Peabody Picture Vocabulary Test]. Circle Pines, Minn.: American Guidance Service.

Early, D. M., Bryant, D. M., Pianta, R. C., Clifford, R. M., Burchinal, M. R., Ritchie, S., et al. (2006). Are teachers' education, major, and credentials related to classroom quality and children's academic gains in pre-kindergarten? Early Childhood Research Quarterly 21: 174-195. DOI: 10.1016/j. ecresq.2006.04.004.

Early, D. M., Maxwell, K. L., Burchinal, M., Alva, S., Bender, R. H., Bryant, D., et al. (2007). Teachers' education, classroom quality, and young children's academic skills: Results from seven studies of preschool programs. Child Development 78: 558-580. DOI: 10.1111/j.1467-8624.2007.01014.x.

Early, D. M., and Winton, P. J. (2001). Preparing the workforce: Early childhood teacher preparation at 2-and 4-year institutions of higher education. Early Childhood Research Quarterly 16: 285-306. DOI: $10.1177 / 105381510502700206$.

Enders, C. K., and Tofighi, D. (2007). Centering predictor variables in cross-sectional multilevel models: A new look at an old issue. Psychological Methods 12: 121-138. DOI: 10.1037/1082-989X.12.2.121.

Entwisle, D. R., Alexander, K. L., Pallas, A. M., and Cadigan, D. (1987). The emergent academic selfimage of first graders: Its response to social structure. Child Development 58: 1,190-1,206. DOI: $10.2307 / 1130614$.

Epstein, A. S. (1999). Pathways to quality in Head Start, public school and private nonprofit early childhood programs. Journal of Research in Childhood Education 13: 101-119.

Epstein, J. L. (2001). School, Family, and Community Partnerships: Preparing Educators and Improving Schools. Boulder, Colo.: Westview.

Fantuzzo, J. F., Bulotsky-Shearer, R., McDermott, P., McWayne, C., Frye, D., and Perlman, S. (2007). Investigation of dimensions of social-emotional classroom behavior and school readiness for lowincome urban preschool children. School Psychology Review 36: 44-62.

Fantuzzo, J. F., McWayne, C., Perry, M. A., and Childes, S. (2004). Multiple dimensions of family involvement and their relations to behavioral and learning competencies for urban, low income children. School Psychology Review 33: 467-480.

Fukkink, R. G., and Lont, A. (2007). Does training matter? A meta-analysis and review of caregiver training studies. Early Childhood Research Quarterly 22: 294-311. DOI: 10.1016/j.ecresq.2007.04.005. 
Fulligni, A. S., Howes, C., Lara-Cinisomo, S., and Karoly, L. (2009). Diverse pathways in early childhood professional development: an exploration of early educators in public preschools, private preschools, and family child care homes. Early Education and Development 20: 507-526. DOI: $10.1080 / 10409280902783483$.

Gerber, E. B., Whitebook, M., and Weinstein, R. S. (2007). At the heart of child care: Predictors of teacher sensitivity in center-based child care. Early Childhood Research Quarterly 22: 327-346. DOI: 10.1016/j. ecresq.2006.12.003.

Gerde, H. K., and Powell, D. R. (2009). Teacher education, book-reading practices, and children's language growth across one year of Head Start. Early Education and Development 20: 211-237. DOI: $10.1080 / 10409280802595417$.

Greenwald, R., Hedges, L. V., and Laine, R. D. (1996). The effect of school resources on student achievement. Review of Educational Research 66: 361-396.

Gresham, F. M., and Elliott, S. N. (1990). Social Skills Rating System. Circle Pines, Minn.: American Guidance Service.

Guskey, T. R. (2003). Scooping up meaningful evidence. Journal of Staff Development 24: 27-30.

Harms, T., Clifford, R. M., and Cryer, D. (1998, 2005). The Early Childhood Environmental Rating Scale, Revised edition. New York: Teachers College Press.

Hill, N. E., and Craft, S. A. (2003). Parent-school involvement and school performance: mediated pathways among socioeconomically comparable African American and Euro-American families. Journal of Educational Psychology 95: 74-83. DOI: 10.1037/0022-0663.95.1.74.

Hindman, A. H., and Morrison, F. J. (2011). Family involvement and educator outreach in Head Start. The Elementary School Journal 111: 359-386. DOI: 10.1086/657651.

Honig, A. S., and Hirallal, A. (1998). Which counts more for excellence in childcare staff-years in service, education level or ECE coursework? Early Child Development and Care 145: 31-46.

Hoover-Dempsey, K. V., Bassler, O. C., and Brissie, J. S. (1992). Exploration in parent-school relations. Journal of Educational Research 85: 287-294. DOI: 10.1080/00220671.1992.9941128.

Hoover-Dempsey, K. V., Walker, J. M. T., Jones, K. P., and Reed, R. P. (2002). Teacher involving parents (TIP): Results of an in-service teacher education program for enhancing parental involvement. Teaching and Teacher Education 18: 843-867. DOI: 10.1016/S0742-051X(02)00047-1.

Howes, C., Burchinal, M., Pianta, R., Bryant, D., Early, D., Clifford, R., et al. (2008). Ready to learn? Children's pre-academic achievement in pre-kindergarten programs. Early Childhood Research Quarterly 23: 27-50. DOI: 10.1016/j.ecresq.2007.05.002.

Howes, C., James, J., and Ritchie, S. (2003). Pathways to effective teaching. Early Childhood Research Quarterly 18: 104-120. DOI: 10.1016/S0885-2006(03)00008-5.

Jacobs, G. M. (2001). Providing the scaffold: A model for early childhood/primary teacher preparation. Early Childhood Education Journal 29: 125-130. DOI: 10.1023/ A:1012581113983.

Justice, L. M., Mashburn, A. J., Hamre, B. K., and Pianta, R. C. (2008). Quality of language and literacy instruction in preschool classrooms serving at-risk pupils. Early Childhood Research Quarterly 23: 5168. DOI: 10.1016/j.ecresq.2007.09.004.

Kelley, P., and Camilli, G. (2007). The Impact of Teacher Education on Outcomes in Center-Based Early Childhood Education Programs: A Meta-Analysis. New Brunswick, N.J.: National Institute for Early Education Research.

Lamb, M. E., and Ahnert, L. (2007). Nonparental child care: context, concepts, correlates, and consequences. In: W. Damon and R. M. Lerner (Editors), Handbook of Child Psychology. Hoboken, N.J.: Wiley.

Logan, J. A. R., Piasta, S. B., Justice, L. M., Schatschneider, C., and Petrill, S. (2011). Children's attendance rates and quality of teacher-child interactionsinat-risk preschoolclassrooms: contribution tochildren's expressive language growth. Child and Youth Care Forum 40: 457-477. DOI: 10.1007/s10566011-9142-x.

Magnuson, K. A., Lahaie, C., and Waldfogel, J. (2006). Preschool and school readiness of children of immigrants. Social Science Quarterly 87: 1,241-1,262. DOI: 10.1111/j.1540-6237.2006.00426.x.

Mashburn, A. J., Pianta, R. C., Hamre, B. K., Downer, J. T., Barbarin, O. A., Bryant, D., et al. (2008). Measures of classroom quality in prekindergarten and children's development of academic, language, and social skills. Child Development 79: 732-749. DOI: 10.1111/j.1467-8624.2008.01154.x.

Matthews, J. S., Ponitz, C. C., and Morrison, F. J. (2009). Early gender differences in self-regulation and academic achievement. Journal of Educational Psychology 101: 689-704. DOI: 10.1037/a0014240.

Maxwell, K. L., Feild, C. C., and Clifford, R. M. (2005). Defining and measuring professional development in early childhood research. In: M. Zaslow and I. Martinez-Beck (Editors), Critical Issues in Early Childhood Professional Development (pp. 21-48). Baltimore: Paul H. Brookes.

McClelland, M. M., and Wanless, S. B. (2012). Growing up with assets and risks: the importance of self-regulation for academic achievement. Research in Human Development 9: 278-297. DOI: 10.1080/15427609.2012.729907. 
McDermott, P. A., Green, L. F., Francis, J. M., and Stott, D. H. (2000). The Preschool Learning Behaviors Scale. Philadelphia: Edumertric \& Clinical Science.

McLoyd, V. C. (1998). Socioeconomic disadvantage and child development. American Psychologist 53: 185-204. DOI: 10.1037/0003-066X.53.2.185.

McWayne, C. M., Campos, R., and Owsianik, M. (2008). A multidimensional, multilevel examination of mother and father involvement among culturally diverse Head Start families. Journal of School Psychology 46: 551-573. DOI: 10.1016/j/jsp.2008.06.001.

McWayne, C. M., Fantuzzo, J. W., and McDermott, P. A. (2004). Preschool competency in context: An investigation of the unique contribution of child competencies to early academic success. Developmental Psychology 40: 633-645. DOI: 10.1037/0012-1649.40.4.633.

Muthén, B. O., and Muthén, L. K. (2010a). Mplus (Version 6). Los Angeles, Calif.: Author.

Muthén, L. K., and Muthén, B. O. (2010b). Mplus User's Guide (6th ed.). Los Angeles, Calif.: Author.

National Association for the Education of Young Children. (2009). NAEYC standards for early childhood professional preparation. Retrieved from http:/ / www.naeyc.org.

National Research Council. (2001). Committee on early childhood pedagogy. In: B. T. Bowman, M. S. Donovan, and M. S. Burns (Editors), Eager to Learn: Educating Our Preschoolers. Washington, D.C.: National Academy Press.

Neuman, S. B., and Cunningham, L. (2009). The impact of professional development and coaching on early language and literacy instructional practices. American Educational Research Journal 46: 532-566. DOI: $10.3102 / 0002831208328088$.

NICHD Early Child Care Research Network. (2002a). Child care structure > process > outcome: direct and indirecteffects of caregiving quality on young children's development. Psychological Science 13:199-206.

NICHD Early Child Care Research Network. (2002b). Early child care and children's development prior to school entry: results from the NICHD Study of Early Child Care. American Educational Research Journal 39: 133-164. DOI: 10.3102/00028312039001133.

NICHD Early Child Care Research Network. (2002c). The relation of global first grade classroom environment to structural classroom features and teacher and student behaviors. The Elementary School Journal 102: 367-387.

NICHD Early Child Care Research Network. (2003). Does quality of child care affect child outcomes at age 41/2? Developmental Psychology 39: 451-469.

Office of Head Start. (2011). Parent, Family, and Community Engagement Framework. Head Start Approach to School Readiness. Washington, D.C.: Administration for Children and Families, U.S. Department of Health and Human Services.

Office of Planning, Research and Evaluation. (2010). Compendium of quality rating systems and evaluations. Washington, D.C.: Administration for Children and Families.

Peisner-Feinberg, E., Burchinal, M., Clifford, R., Culkin, M., Howes, C., Kagan, S., et al. (2001). The relation of preschool child-care quality to children's cognitive and social developmental trajectories through second grade. Child Development 72: 1,534-1,553.

Peisner-Feinberg, E. S., and Yazejian, N. (2010). Research on program quality. In P. W. Wesley and V. Buysse (Editors), The Quest for Quality: Promising Innovations for Early Childhood Programs (pp. 21-45). Baltimore, Md.: Paul H. Brookes. Peske, H. G., and Haycock, K. (2006). Teaching Inequality: How Poor and Minority Students Are Shortchanged on Teacher Quality: A Report and Recommendations by the Education Trust. Washington, D.C.: The Education Trust.

Pianta, R., Howes, C., Burchinal, M., Bryant, D., Clifford, R., Early, D., et al. (2005). Features of prekindergarten programs, classrooms, and teachers: do they predict observed classroom quality and child-teacher interactions? Applied Developmental Science 9: 144-159. DOI: 10.1207/s1532480xads0903_2.

Pianta, R. C., La Paro, K. M., and Hamre, B. K. (2008). Classroom Assessment Scoring System ${ }^{\mathrm{TM}}$ (CLASS $^{\mathrm{TM}}$ ) Manual: Pre-K. Baltimore, Md.: Paul H. Brookes.

Powell, D. R. (2001). Visions and realities of achieving partnership: Parent-school relationships at the turn of the century. In: A. Göncü and E. L. Klein (Editors), Children in Play, Story, and School (pp. 333-357). New York: Guilford Press.

Powell, D. R. (2009). The Head Start program. In: J. Roopnarine and J. E. Johnson (Editors), Approaches to Early Childhood Education (5th ed., pp. 48-67). Upper Saddle River, N.J.: Merrill/Pearson.

Powell, D. R., Diamond, K. E., Burchinal, M. R., and Koehler, M. J. (2008). Effects of an early literacy professional development intervention on head start teachers and children. Journal of Educational Psychology 102: 299-312. DOI: 10.1037/a0017763.

Powell, D. R., Son, S.-H., File, N., and San Juan, R. R. (2010). Parent-school relationships and children's academic and social outcomes in public school pre-kindergarten. Journal of School Psychology 48: 269292. DOI: $10.1016 /$ j.jsp.2010.03.002. 
Raudenbush, S., and Bryk, A. (2002). Hierarchical Linear Models: Applications and Data Analysis Methods (2nd ed.). Thousand Oaks, Calif.: Sage.

Raver, C. C., Jones, S. M., Li-Grining, C. P., Metzger, M., Champion, K. M., and Sardin, L. (2008). Improving preschool classroom processes: preliminary findings from a randomized trial implemented in Head Start settings. Early Childhood Research Quarterly 23: 10-26. DOI: 10.1016/j.ecresq.2007.09.001.

Rimm-Kaufman, S. E., Pianta, R. C., Cox, M. J., and Bradley, R. H. (2003). Teacher-rated family involvement and children's social and academic outcomes in kindergarten. Early Education and Development 14: 179-198. DOI: 10.1207/s15566935eed1402_3.

Rudd, L. C., Lambert, M. C., Satterwhite, M., and Smith, C. H. (2009). Professional development + coaching = enhanced teaching: increasing usage of math mediated language in preschool classrooms. Early Childhood Education Journal 37: 63-69. DOI: 10.1007/s10643-009-0320-5.

Sakai, L., Whitebook, M., Wishard, A., and Howes, C. (2003). Evaluating the early childhood rating scale: assessing differences between the first and revised edition. Early Childhood Research Quarterly 18: 427-445. DOI: 10.1016/j.ecresq.2003.09.004.

Sektnan, M., McClelland, M. M., Acock, A. C., and Morrison, F. J. (2010). Early family risk, behavioral regulation, and children's academic achievement. Early Childhood Research Quarterly 25: 464-479. DOI: $10.1016 /$ j.ecresq.2010.02.005.

Stoll, L., Bolam, R., McMahon, A., Wallace, M., and Thomas, S. (2006). Professional learning communities: a review of the literature. Journal of Educational Change 7: 221-258.

Tout, K., Zaslow, M., and Berry, D. (2005). Quality and qualifications: links between professional development and quality in early care and education settings. In: M. Zaslow and I. Martinez-Beck (Editors), Critical Issues in Early Childhood Professional Development (pp. 77-110). Baltimore, Md.: Paul H. Brookes.

U.S. Department of Health and Human Services. Administration for Children and Families. (January 2010). Head Start Impact Study. Technical report. Washington, D.C.

Vandell, D. L., and Wolfe, B. (2000). Child Care Quality: Does It Matter and Does It Need to Be Improved? Washington, D.C.: Office of the Assistant Secretary for Planning and Evaluation, U.S. Department of Health and Human Services. Also available as (Special Report No. 78) University of WisconsinMadison, Institute for Research on Poverty.

Wasik, B. A., Bond, M. A., and Hindman, A. (2006). The effects of a language and literacy intervention on Head Start children and teachers. Journal of Educational Psychology 98: 63-74. DOI: 10.1037/00220663.98.1.63.

Webster-Stratton, C., Reid, M. J., and Hammond, M. (2001). Preventing conduct problems, promoting social competence: a parent and teacher training partnership in Head Start. Journal of Clinical Child E Adolescent Psychology 30: 283-302. DOI: 10.1207/S15374424JCCP3003_2.

Woodcock, R. W., and Johnson, M. B. (1989). Woodcock-Johnson Psycho-Educational Battery, Revised. Itasca, Ill.: Riverside Publishing.

Woodcock, R. W., and Muñoz-Sandoval, A. F. (1996). Bateria Woodcock-Muñoz: Pruebas de Aprovechamiento, Revisada. Itasca, Ill.: Riverside Publishing.

Zaslow, M., and Martinez-Beck, I. (2006). Critical Issues in Early Childhood Professional Development. Baltimore: Paul H. Brookes.

Zellman, G. L., and Perlman, M. (2006). Parent involvement in child care settings: conceptual and measurement issues. Early Child Development and Care 176: 521-538. DOI: 10.1080/03004430500147490.

Zill, N., Sorongon, A., Kim, K., Clark, C., and Woolverton, M. (2006). Children's Outcomes and Program Quality in Head Start. FACES 2003 Research Brief. Washington, D.C.: U.S. Administration for Children and Families. 